\title{
Perceived Effectiveness of Municipal Financial Management on the Performance of Inventory Stock Management in Local Government of South Africa
}

\author{
*Zwelihle Wiseman NZUZA, Lawrence Mpele LEKHANYA \\ Durban University of Technology, South Africa \\ *zwnzuza@gmail.com
}

\begin{abstract}
This paper reports on the perceived effectiveness of municipal financial management (MFM), on the performance of inventory stock management, by South African local government. The study aimed to evaluate and discuss various factors affecting the effectiveness of MFM on the performance of inventory stock management, in a local municipal government of South Africa, with specific reference to the Kwa-Zulu Natal (KZN) Province. The MFM Act was used as a theoretical framework for the study, and a quantitative research method was applied. The questionnaire was formulated based on information obtained from the literature, and was distributed to only one KZN local government department. The sample consisted of 57 respondents, selected using a census sampling method. The results indicate that there is significant relationships between experience and performance of inventory stock management $\left(\mathrm{p}=.003 \mathrm{a}, \mathrm{b}^{*}\right)$, experience and effectiveness/efficiency of MFM $\left(\mathrm{p}=.000 \mathrm{a}, \mathrm{b}^{*}\right)$, as well as experience and the economic viability of MFM $\left(\mathrm{p}=.000 \mathrm{~b}, \mathrm{c}^{*}\right)$.Interestingly, the respondents also indicated that, although there is good inventory stock management, there is a weak relationship between the effectiveness/efficiency, economic viability, and transparency of MFM. This study recommends that further research should aim to advance financial management skills in South African local government, in order to build financial management capacity to deal with inventory stock management issues. This should enable communication with other related structures and improve the understanding of each other's efforts in the organization.
\end{abstract}

Keywords: Municipal financial management (MFM), effectiveness, economically, transparency, inventory stock management

\section{Introduction}

Recent studies by Aikins (2011) and Attila \&Cristina (2010), indicate that local government authorities have doubts regarding municipal financial management (MFM), however, it has also been noted that local government authorities use MFM to regulate the finances of the state. This regulation includes that of inventory stock management. Siali, Liu \& Kie (2013) describe inventory stock management as a function that involves making the financial decisions on inventory stock control. However, literature reveals that the apparent MFM presently used by local government may not be sufficient as the most appropriate approach for inventory stock management. An experimental study, conducted by Aikins (2011) in the United State of America (USA), recommends more studies to investigate the effectiveness of MFM in local governments. Likewise, Luby (2013) reveals that, the need to examine the effectiveness of MFM in all spheres of government globally, has not gained momentum. In recent years, the actuality of the South African local government has been faced with many challenges concerning inventory stock management to improve performance in strengthening audit reports (Audit to build public confidence, 2013).This research seeks to investigate the perceived effectiveness of MFM on the performance of inventory stock management in South African local government. The understanding will shed light on the role played by MFM in managing inventory stock by the South African local government.

\section{Aim and objectives}

Aim: This study aims to identify and discuss various factors influencing the effectiveness of MFM on the performance of inventory stock management and how local government employees' perceptions towards inventory stock management are created.

\section{Objectives}

- To evaluate the perceived performance of inventory stock management in a local government department of KZN; and 
- To identify factors and examine to what extent these factors influence the effectiveness of MFM on the performance of inventory stock management in KZN local government.

Theoretical framework: There are many studies conducted under the MFM framework that examine financial compliance, such as those conducted in Buffalo City, Steve Tshawete, Swartl \& Emakhazeni (Graves \& Dollery, 2009). The framework emphasizes the prevention of unauthorized, irregular, and fruitless expenditure on inventory stock by local government authorities, which includes the safeguarding of local government resources. This framework is outlined in the South African Municipal Financial Management Act (MFMA), act No. 56 of 2003. The act has indicated collective approaches, which take effectiveness, efficiency, economic viability, and transparency into account.

\section{Literature Review}

Debts and budgeting have been viewed by many people in the past, as major facets of MFM (Tikk \& Almann, 2011) and include procurement and auditing aspects (Roman, 2013; Aikins, 2011). Effectiveness, efficiency, economic viability, and transparency, are mentioned as contributing most to MFMA. The details of these are provided below:

Effectiveness and efficiency: MFMis a decision-making structure or process that monitors and controls the finances of local government, in order to achieve desired goals(Graves \& Dollery, 2009).The efficiency of MFM depends on the truthfulness of management, when controlling financial agency problems that may occur (Kamnikar, Kamnikar \& Burrowes, 2011). There are, nevertheless, many issues reported concerning the effectiveness of MFM around the world. Eze \& Harrison (2013) report a major problem affecting the efficiency of MFM, is that of the level of commitment. The Audit to build public confidence Report (2013) highlights the inefficiency of MFM in South Africa, and states that it is a result of the poor academic background of responsible officials. Adamauskas \& Krusinskas (2012), on the other hand, support the premise that the inefficiency of MFM seems to be caused by poor communication between local government officials. This is justified by a recent study, conducted in the USA, among 291 local government finance directors, with the conclusion that MFM has failed to result improper management decisions (Matkin, 2010).

Research by Graves \&Dollery (2009) reveals that the causes of poor MFM can be attributed to individuals' failure to take responsibility and be accountable. Eze \& Harrison (2013) add that the designed set of policies and principles are the cornerstones for successful MFM. Evidence, from 24 local governments in New York State, illustrates accountability problems with MFM (Huefner, 2011). According to Arbe (2013), it is estimated that 98 percent of the world's inventory stock is spent through MFM by local government. In South Africa and Angola, MFM accounts for more than two quarters of inventory stocks and for more than three quarters of national inventory stock. In Malawi MFM accounts for two quarters, while more than three quarters of inventory stock can be attributed to MFM in Uganda, and three quarters in Kenya. The area of inventory stock management is increasingly deceitful about various factors concerning the effectiveness of MFM (Aikins, 2011). Mwakibinga \& Buvik (2013) believe that many local government procurements, which are incurring wasteful expenditure on inventory stock and considered too weak, are the result of poor MFM in inventory stock management. The operating procedures and internal control systems are factors that impede the functioning of MFM in the local government sector (Bonson, Torres, Royo \& Floresc, 2012). The performance of MFM in a public sector in Europe was affected by these factors (Bovis, 2010). It is also apparent that the increase of government taxes is closely related to the ineffectiveness of the MFM function (Fausto, 2010). According to Mackevicius \& Raulinaitiene (2007), the failure of MFM to operate efficiently, can be attributed to preceding scholars and practitioners.

Transparency: Through MFM, almost every local government has an ultimate goal of becoming a transparent organization in reporting finances to citizens. According to Liou (2013), wasteful expenditure can be overcome through enforcement of transparency and openness. Failure of MFM practitioners to apply principles of transparency and openness, has led local governments to function critically in all spheres of operation (Kamnikar et al., 2011), while the failure of MFM practitioners, in enforcing transparency in local government, has increased the work of external auditors (Bonson et al., 2012). Abushamsieh, Lopez, Hernandez \& Ortiz (2013) suggest that, failure to use information technology, is a contributing factor to poor MFM transparency. Literature supports that political involvement and group influence are the two main factors affecting MFM transparency in local government (Grimmelikhuijsen \& Welch 2012). Seminega (2012) reports that, MFM continues to fail in being transparent; because its 
principles are still difficult for official's to understand. Mwakibinga \& Buvik (2013) indicate that nontransparency by MFM officials contributes to the lack of accuracy enforcement, according to MFM rules. The author's further suggests that, failure by departments to communicate, adds to the anxiety of being transparent, illustrating that poor monitoring, by the executive management of Tanzania's public sector, was found to impede a desired level of transparency. According to Mackevicius \& Raulinaitiene (2007), the public has a constitutional right to obtain access to the financial statements produced by local government. This includes the right to have a point of view on whether public resources are utilized effectively and efficiently. The authors support a study to investigate perceived transparency of MFM, simply because similar studies were carried out a long time ago on an academic level, by only a few Lithuanian authors (Alekneviciene, 2005; Buckuniene, 2002; Levisauskaite \& Ruskys, 2003; Mackevicius et al. 2007; Meidunas \& Puzinauskas, 2003).These Lithuanian authors found that the MFM framework requires more attention with regards to the implication of policies. This issue has not yet been resolved (Luby, 2013).

Economic viability: MFM fosters public sectors to operate economically (Kamnikar et al, 2011).An experimental study, by16 procurement practitioners in local government in England, shows that failure to save costs is a matter of uneconomical MFM principles (Preuss, 2007). Herath (2012) echoes the sentiment that failure of local government to control finances is directly related to the inefficiencies of MFM. These authors state that spending by local government has a significant relationship with MFM. Improvement of MFM has significant potential for savings and growing the country economically (Jovanovic \& Benkovic, 2012). Greiner \& Semmler (2000), cited by Groneck (2011), indicate that the principles of MFM have a negative impact on the economic growth of society. In support, Minea \& Villieu (2009) confirm the negative impact by MFM on the economic strategy of the country. Agenor \& Yilmaz (2011) illustrate that the negative effect of MFM, in the control of public resources, is as a result of negligent management. The authors also claim this is due to the fact, that there is no internal structure designed to ensure the smooth running of the MFM framework. Smith (2013) reveals that MFM is the only tool used by public governments to preserve resources, such as inventory stock. Alam (2008) suggests that inventory stock management can be successful only if MFM works economically to insist on the preservation of available resources. The economic difficulties faced in the past, promote the need to improve the effectiveness of the MFM framework. In this regard, much of the writing on the topic only stresses the danger of increasing local government expenditure, yet it does not cover the inventory stock management aspect (Fausto, 2010).

Inventory stock management: There are many reasons that make inventory stock management very important in organizations. Burja \& Burja (2010) indicate that the need for inventory stock management includes providing information needed to justify managerial decisions, which will lead to better organizational performance. Kumar \& Ganguli (2009) suggest that, by improving inventory stock management, the most efficient and cost effective ways, to offer quality goods and services to valued customers, can be determined. Siali, Liu \&Kie (2013) indicate that, improving inventory stock management has a positive link with marketing approaches and the use of advanced inventory control technologies. Smith (2013) states that, improving inventory stock management, is a root reason for better performance of working capital. Basaran (2013),through a study of305 large manufacturing enterprises located in Turkey, indicates that efficient performance on inventory stock management is affected by the demand and financial capacity related matters. Umakanta \& Chaitanya (2012) articulate that it is imperative for a public government sector to ensure its inventory stock management is strong enough to support financial decisions and other related tasks. According to Huefner (2011), a good inventory stock management can be categorized with good financial strategies. A good financial strategy of inventory stock management improves stock purchase decisions, saves time and money, increases efficiency, and improves customer service.

\section{Methodology}

A literature review was used as the source of information from which to formulate the questionnaire, which consisted of closed-ended questions.

Population: A questionnaire was used to collect data from 80 staff members regarding their perceptions on the effectiveness of MFM in inventory stock management. The study was confined to the finance section of a local government department, and there were three target populations; namely that of the 
budget, audit and expenditure's sections. The target population selected for investigation included members of staff in the public sector of South Africa.

Questionnaire administration: The standardised, self-administered questionnaire comprised a general section for biographical information. There was also a section dealing with inventory stock management, while another section dealt with the effectiveness of MFM on the performance of inventory stock management. A mix of nominal items in the questionnaire was employed in the biographical section. Apart from the demographics, all variables were measured using a 5-point Likert scale. The survey instrument comprised the following main questions.

\section{Table 1: Summary of key research questions}

\begin{tabular}{|c|c|}
\hline Research area & Question \\
\hline \multicolumn{2}{|l|}{ Independent variables } \\
\hline $\begin{array}{l}\text { Inventory stock } \\
\text { management }\end{array}$ & $\begin{array}{l}\text { 7.1Is performance of inventory stock management good? } \\
\text { Response alternatives: strongly agree, agree, neutral, strongly disagree, and } \\
\text { disagree. }\end{array}$ \\
\hline \multicolumn{2}{|l|}{ Dependent variables } \\
\hline \multirow{10}{*}{$\begin{array}{lr}\text { Role of MFM } & \text { on the } \\
\text { performance } & \text { of } \\
\text { inventory } & \text { stock } \\
\text { management } & \end{array}$} & $\begin{array}{l}\text { 8.1Do you think MFM effectively improves performance of inventory stock } \\
\text { management? }\end{array}$ \\
\hline & $\begin{array}{l}\text { Response alternatives: strongly agree, agree, neutral, strongly disagree, and } \\
\text { disagree. }\end{array}$ \\
\hline & $\begin{array}{l}\text { 8.2Do you think the Principles of MFM are practical in inventory stock } \\
\text { management? }\end{array}$ \\
\hline & $\begin{array}{l}\text { Response alternatives: strongly agree, agree, neutral, strongly disagree, and } \\
\text { disagree. }\end{array}$ \\
\hline & 8.3 Do you think MFM is economically effective? \\
\hline & $\begin{array}{l}\text { Response alternatives: strongly agree, agree, neutral, strongly disagree, and } \\
\text { disagree. }\end{array}$ \\
\hline & $\begin{array}{l}\text { 8.4 Do you think MFM assists with good financial decisions in inventory stock } \\
\text { management? }\end{array}$ \\
\hline & $\begin{array}{l}\text { Response alternatives: strongly agree, agree, neutral, strongly disagree, and } \\
\text { disagree. }\end{array}$ \\
\hline & $\begin{array}{l}\text { 8.5 Do you think MFM enforces employee transparency in inventory stock } \\
\text { management? }\end{array}$ \\
\hline & $\begin{array}{l}\text { Response alternatives: strongly agree, agree, neutral, strongly disagree, and } \\
\text { disagree. }\end{array}$ \\
\hline
\end{tabular}

Data collection: The researcher collected a total of 80 responses (57 full and 23 partially completed questionnaires). The23partially completed questionnaires were discarded, resulting in a final sample of 57.

Data analysis: Using frequencies, data was analysed using the Statistical Package for Social Sciences (SPSS) version 21.0. Descriptive and inferential statistics were used to analyse the quantitative data. Variables were screened, identifying those that influenced the dependent variables of the study. In order to test relationships, cross-tabulations, with the appropriate inferential statistics (Chi-square test), were used.

Reliability and Validity: Reliability tests performed by this study were conclusive for all the questionnaire items (Cronbach's alpha $>0.5$ ). The survey's data also fully passed the validity test, as all Likert scale items split into exactly five components. All tests were performed with a confidence level of 0.577 , thus concluding that the reliability of the study was acceptable. 


\section{Results and discussions}

A comprehensive literature review was done and used to form the questionnaire for this study, which led to the findings of the results, presented below.

Table 2: Difference between the performance of inventory stock management and the effectiveness of MFM

\begin{tabular}{|c|c|c|c|c|c|c|c|c|c|c|c|c|c|}
\hline \multirow{2}{*}{\multicolumn{2}{|c|}{ Statement }} & \multicolumn{4}{|c|}{$\begin{array}{l}\text { Q7.1 } \\
\text { Strongly } \\
\text { agree }\end{array}$} & \multicolumn{2}{|c|}{ Neutral } & \multicolumn{2}{|c|}{ Disagree } & \multicolumn{2}{|c|}{$\begin{array}{l}\text { Strongly } \\
\text { Disagree }\end{array}$} & \multicolumn{2}{|c|}{ Total } \\
\hline & & $\mathrm{n}$ & $\%$ & $\mathbf{n}$ & $\%$ & $\mathbf{n}$ & $\%$ & $\mathbf{N}$ & $\%$ & $\mathbf{n}$ & $\%$ & $\mathbf{n}$ & $\%$ \\
\hline \multirow[t]{6}{*}{ Q8.1 } & $\begin{array}{l}\text { Strongly } \\
\text { agree }\end{array}$ & 2 & $3.5 \%$ & 5 & $8.8 \%$ & 0 & $0.0 \%$ & 1 & $1.8 \%$ & 0 & $0.0 \%$ & 8 & $14.0 \%$ \\
\hline & Agree & 9 & $15.8 \%$ & 3 & $5.3 \%$ & 0 & $0.0 \%$ & 0 & $0.0 \%$ & 1 & $1.8 \%$ & 13 & $22.8 \%$ \\
\hline & Neutral & 16 & $28.1 \%$ & 4 & $7.0 \%$ & 0 & $0.0 \%$ & 1 & $1.8 \%$ & 3 & $5.3 \%$ & 24 & $42.1 \%$ \\
\hline & Disagree & 1 & $1.8 \%$ & 0 & $0.0 \%$ & 3 & $5.3 \%$ & 0 & $0.0 \%$ & 0 & $0.0 \%$ & 4 & $7.0 \%$ \\
\hline & $\begin{array}{l}\text { Strongly } \\
\text { Disagree }\end{array}$ & 8 & $14.0 \%$ & 0 & $0.0 \%$ & 0 & $0.0 \%$ & 0 & $0.0 \%$ & 0 & $0.0 \%$ & 8 & $14.0 \%$ \\
\hline & Total & 36 & $63.2 \%$ & 12 & $21.1 \%$ & 3 & $5.3 \%$ & 2 & $\begin{array}{r}3.5 \% \\
\mathrm{Va}\end{array}$ & $\begin{array}{l}4 \\
\text { lue }\end{array}$ & $7.0 \%$ & $\begin{array}{l}57 \\
p\end{array}$ & $100.0 \%$ \\
\hline \multicolumn{2}{|c|}{ Q7.1 * Q8.1 } & \multicolumn{4}{|c|}{ Ordinal by Ordinal } & \multicolumn{3}{|c|}{ Kendall's tau-b } & \multicolumn{2}{|c|}{$\begin{array}{l}\text { Value } \\
-.172\end{array}$} & & \multicolumn{2}{|c|}{.104} \\
\hline
\end{tabular}

*. The Chi-square statistic is significant at the .05 level.

Respondents were asked whether MFM effectively improves the performance of inventory stock management. In Table 2, the results show that 24 (42.1 percent) of the respondents were neutral regarding the statement, while21 (36.8 percent) of the respondents strongly agree or agree that MFM effectively improves the performance of inventory stock management, and12 (21 percent) of the respondents disagree with the statement. In this regard, a Chi-square $(x)$ test showed a p value of 0.104 , which is greater than 0.05 . The results reveal that there is no statistically significant relationship between the performance of inventory stock management and MFM effectiveness. These two variables are independent of each other. The association is not significant at a95 percent level ( $p>0.05)$. Therefore, the performance of inventory stock management is not related to the effectiveness of MFM.

Table 3: Differences between effectiveness of MFM and age

\begin{tabular}{|c|c|c|c|c|c|c|c|c|c|c|c|c|c|}
\hline \multirow{2}{*}{\multicolumn{2}{|c|}{ Statement }} & \multicolumn{2}{|c|}{$\begin{array}{l}8.1 \\
\text { Strongly } \\
\text { agree } \\
\end{array}$} & \multicolumn{2}{|c|}{ Agree } & \multicolumn{2}{|c|}{ Neutral } & \multicolumn{2}{|c|}{ Disagree } & \multicolumn{2}{|c|}{$\begin{array}{l}\text { Strongly } \\
\text { Disagree }\end{array}$} & \multicolumn{2}{|c|}{ Total } \\
\hline & & n & $\%$ & $\mathbf{n}$ & $\%$ & $\mathbf{n}$ & $\%$ & $\mathbf{n}$ & $\%$ & $\mathbf{n}$ & $\%$ & $\mathbf{n}$ & $\%$ \\
\hline \multirow[t]{5}{*}{ Age } & $18-25$ & 0 & $0.0 \%$ & 1 & $1.8 \%$ & 0 & $0.0 \%$ & 0 & $0.0 \%$ & 2 & $3.5 \%$ & 3 & $5.3 \%$ \\
\hline & $26-35$ & 6 & $10.5 \%$ & 3 & $5.3 \%$ & 6 & $10.5 \%$ & 0 & $0.0 \%$ & 0 & $0.0 \%$ & 15 & $26.3 \%$ \\
\hline & $36-45$ & 0 & $0.0 \%$ & 6 & $10.5 \%$ & 7 & $12.3 \%$ & 0 & $0.0 \%$ & 0 & $0.0 \%$ & 13 & $22.8 \%$ \\
\hline & 45 and above & 2 & $3.5 \%$ & 3 & $5.3 \%$ & 11 & $19.3 \%$ & 4 & $7.0 \%$ & 6 & $10.5 \%$ & 26 & $45.6 \%$ \\
\hline & Total & 8 & $14.0 \%$ & 13 & $22.8 \%$ & 24 & $42.1 \%$ & 4 & $7.0 \%$ & 8 & $14.0 \%$ & 57 & $100.0 \%$ \\
\hline
\end{tabular}

Chi-square $=32.788, \mathrm{df}=12, \mathrm{p}=.001^{\mathrm{a}, \mathrm{b}} *$

*. The Chi-square statistic is significant at the .05 level.

As indicated by Table 3, the majority of the respondents, 26 (45.6percent), are aged at 45 years and above, 15 (26.3 percent) are aged between 26 to 35 years, 13 (22.8 percent) are aged between 36 to 45 years, and three (5.3 percent) are aged between 18 and25 years. The findings of this study were therefore, based on the responses from mature respondents. A Chi-square (x) test performed indicates a $\mathrm{p}$ value of 0.001 , which is less than 0.05 . The results reflect a significant association between the effectiveness of MFM and age. The association is significant at a level of95 percent $(\mathrm{p}<0.05)$. Therefore, the effectiveness of MFM and age are inter-related.

Respondents from a South African local government department were asked to indicate their level of work experience in their respective department. As shown in Table 4, 16 (28.1 percent) of the respondents had between nineand12 years of experience, with another 16 (28.1 percent) respondents having between six and nine years experience. Eleven (19.3 percent) of the respondents had between three and six years of experience, nine(15.8 percent) had15 years and more work experience, while 
three(5.3 percent) had between 0 and three years of experience, and two(3.5 percent) had between 12 and15 years work experience. From these results, it is claimed that most responses in this study were from well experienced staff. Furthermore, a Chi-square (x) test result indicates a p value of 0.001 , which is less than 0.05 . The results reflect a significant association between the effectiveness of MFM and experience. The association is significant at the 95 percent level $(\mathrm{p}<0.05)$. Therefore, the effectiveness of MFM and experience are inter-related.

Table 4: Differences between effectiveness of MFM and experience

\begin{tabular}{|c|c|c|c|c|c|c|c|c|c|c|c|}
\hline \multirow[t]{2}{*}{ Statement } & \multicolumn{2}{|c|}{$\begin{array}{l}8.1 \\
\text { Strongly } \\
\text { agree } \\
\end{array}$} & \multicolumn{2}{|c|}{ Agree } & \multicolumn{2}{|c|}{ Neutral } & \multicolumn{2}{|c|}{ Disagree } & $\begin{array}{l}\text { Strongly } \\
\text { Disagree }\end{array}$ & \multicolumn{2}{|c|}{ Total } \\
\hline & $\mathbf{n}$ & $\%$ & $\mathbf{N}$ & $\%$ & $\mathbf{n}$ & $\%$ & $\mathbf{n}$ & $\%$ & n $\%$ & $\mathbf{n}$ & $\%$ \\
\hline Experience0 to 3yrs & 1 & $1.8 \%$ & 1 & $1.8 \%$ & 0 & $0.0 \%$ & 1 & $1.8 \%$ & $0.0 \%$ & 3 & $5.3 \%$ \\
\hline 3 to $6 y r s$ & 0 & $0.0 \%$ & 4 & $7.0 \%$ & 2 & $3.5 \%$ & 0 & $0.0 \%$ & $8.8 \%$ & 11 & $19.3 \%$ \\
\hline 6 to $9 y r s$ & 3 & $5.3 \%$ & 2 & $3.5 \%$ & 9 & $15.8 \%$ & 0 & $0.0 \% 2$ & $3.5 \%$ & 16 & $28.1 \%$ \\
\hline 9 to $12 \mathrm{yrs}$ & 1 & $1.8 \%$ & 2 & $3.5 \%$ & 12 & $21.1 \%$ & 0 & $0.0 \%$ & $1 \quad 1.8 \%$ & 16 & $28.1 \%$ \\
\hline 12 to $15 y r s$ & 2 & $3.5 \%$ & 0 & $0.0 \%$ & 0 & $0.0 \%$ & 0 & $0.0 \%$ & $0.0 \%$ & 2 & $3.5 \%$ \\
\hline 15yrs and above & 1 & $1.8 \%$ & 4 & $7.0 \%$ & 1 & $1.8 \%$ & 3 & $5.3 \%$ & $0 \quad 0.0 \%$ & 9 & $15.8 \%$ \\
\hline Total & 8 & $14.0 \%$ & 13 & $22.8 \%$ & 24 & $42.1 \%$ & & $7.0 \%$ & $8 \quad 14.0 \%$ & 57 & $100.0 \%$ \\
\hline
\end{tabular}

Chi-square $=54.642, \mathrm{df}=20, \mathrm{p}=.000 \mathrm{a}, \mathrm{b} *$

*. The Chi-square statistic is significant at the .05 level.

Table 5: Difference between performance of inventory stock management and MFM principles



*. The Chi-square statistic is significant at the .05 level.

Table 5 indicates that 24 (42.1 percent) of the respondents indicated a neutral response regarding the principles of MFM being practically applicable in inventory stock management, while21 (36.9 percent) of the respondents agree or strongly agree that the principles of MFM are practical for inventory stock management. Twelve (21.1 percent) of the respondents disagree or strongly disagree with the statement. In this regard, a Chi-square $(\mathrm{x})$ test result showed a $\mathrm{p}$ value of 0.050 , which is equal to 0.05 . The results reflect a significant association between the performance of inventory stock management and MFM principles. The association is significant at the 95 percent level $(\mathrm{p}<0.05)$. As a result, performance of inventory stock managementand the principlesof MFM is inter-related.

Table 6 shows that the vast majority, 24 (42.1 percent), of the respondents agree or strongly agree that MFM has an economic influence on the performance of inventory stock management, 17 (29.9 percent) of the respondents disagree or strongly disagree with the statement. A total of16 (28.1 percent) of the respondents indicated a neutral response, as to whether MFM has an economic influence on the performance of inventory stock management. In this respect, a Chi-square ( $\mathrm{x}$ ) test showed a $\mathrm{p}$ value of0.241, which is greater than 0.05 . The results reveal that there is no statistically significant relationship between the performance of inventory stock management and the economic viability of MFM. These two variables are independent of each other. The association is not significant at the 95 percent level ( $p>0.05)$. Therefore, performance of inventory stock management is not related to the economic viability of MFM. 
Table 6: Difference between performance of inventory stock management and economic influence of MFM

\begin{tabular}{|c|c|c|c|c|c|c|c|c|c|c|c|c|}
\hline \multirow[t]{2}{*}{ Statement } & \multicolumn{2}{|c|}{$\begin{array}{l}\text { Q7.1 } \\
\text { Strongly } \\
\text { agree } \\
\end{array}$} & \multicolumn{2}{|c|}{ Agree } & \multicolumn{2}{|c|}{ Neutral } & \multicolumn{2}{|c|}{ Disagree } & \multicolumn{2}{|c|}{$\begin{array}{l}\text { Strongly } \\
\text { Disagree }\end{array}$} & \multicolumn{2}{|c|}{ Total } \\
\hline & $\mathbf{N}$ & $\%$ & $\mathbf{n}$ & $\%$ & n & $\%$ & n & $\%$ & $\mathbf{n}$ & $\%$ & $\mathbf{n}$ & $\%$ \\
\hline $\begin{array}{c}\text { Q8.3 Strongly } \\
\text { agree }\end{array}$ & 1 & $1.8 \%$ & 4 & $7.0 \%$ & 0 & $0.0 \%$ & 1 & $1.8 \%$ & 0 & $0.0 \%$ & 6 & $10.5 \%$ \\
\hline Agree & 15 & $26.3 \%$ & 2 & $3.5 \%$ & 1 & $1.8 \%$ & 0 & $0.0 \%$ & 0 & $0.0 \%$ & 18 & $31.6 \%$ \\
\hline Neutral & 13 & $22.8 \%$ & 3 & $5.3 \%$ & 0 & $0.0 \%$ & 0 & $0.0 \%$ & 0 & $0.0 \%$ & 16 & $28.1 \%$ \\
\hline Disagree & 7 & $12.3 \%$ & 2 & $3.5 \%$ & 2 & $3.5 \%$ & 1 & $1.8 \%$ & 2 & $3.5 \%$ & 14 & $24.6 \%$ \\
\hline $\begin{array}{l}\text { Strongly } \\
\text { Disagree }\end{array}$ & 0 & $0.0 \%$ & 1 & $1.8 \%$ & 0 & $0.0 \%$ & 0 & $0.0 \%$ & 2 & $3.5 \%$ & 3 & $5.3 \%$ \\
\hline Total & 36 & $63.2 \%$ & 12 & $21.1 \%$ & 3 & $5.3 \%$ & 2 & $\begin{array}{r}3.5 \% \\
V\end{array}$ & $\begin{array}{l}4 \\
\text { lue }\end{array}$ & $7.0 \%$ & $\begin{array}{l}57 \\
\mathrm{p}\end{array}$ & $100.0 \%$ \\
\hline $\mathrm{Q} 7.1 * \mathrm{Q} 8.3$ & & Ordinal b & $\mathrm{y} O \mathrm{r}$ & & Ken & 's tau-b & & & & & .241 & \\
\hline
\end{tabular}

*. The Chi-square statistic is significant at the .05 level.

Table 7: Differences between the economic influence of MFM and experience

\begin{tabular}{|c|c|c|c|c|c|c|c|c|c|c|c|c|}
\hline \multirow[t]{2}{*}{ Statement } & \multicolumn{2}{|c|}{$\begin{array}{l}.3 \\
\text { Strongly } \\
\text { agree }\end{array}$} & \multicolumn{2}{|c|}{ Agree } & \multicolumn{2}{|c|}{ Neutral } & \multicolumn{2}{|c|}{ Disagree } & \multicolumn{2}{|c|}{$\begin{array}{l}\text { Strongly } \\
\text { Disagree }\end{array}$} & \multicolumn{2}{|c|}{ Total } \\
\hline & $\mathrm{n}$ & $\%$ & $\mathbf{n}$ & $\%$ & $\mathbf{n}$ & $\%$ & $\mathbf{N}$ & $\%$ & $\mathbf{n}$ & $\%$ & $\mathbf{n}$ & $\%$ \\
\hline Experience 0 to $3 y r s$ & 0 & $0.0 \%$ & 1 & $1.8 \%$ & 0 & $0.0 \%$ & 1 & $1.8 \%$ & 1 & $1.8 \%$ & 3 & $5.3 \%$ \\
\hline 3 to $6 y r s$ & 0 & $0.0 \%$ & 6 & $10.5 \%$ & 5 & $8.8 \%$ & 0 & $0.0 \%$ & 0 & $0.0 \%$ & 11 & $19.3 \%$ \\
\hline 6 to $9 y r s$ & 0 & $0.0 \%$ & 2 & $3.5 \%$ & 10 & $17.5 \%$ & 4 & $7.0 \%$ & 0 & $0.0 \%$ & 16 & $28.1 \%$ \\
\hline 9 to $12 y r s$ & 6 & $10.5 \%$ & 7 & $12.3 \%$ & 0 & $0.0 \%$ & 2 & $3.5 \%$ & 1 & $1.8 \%$ & 16 & $28.1 \%$ \\
\hline 12 to $15 y r s$ & 0 & $0.0 \%$ & 0 & $0.0 \%$ & 0 & $0.0 \%$ & 2 & $3.5 \%$ & 0 & $0.0 \%$ & 2 & $3.5 \%$ \\
\hline $15 y r s$ and abov & & $0.0 \%$ & 2 & $3.5 \%$ & 1 & $1.8 \%$ & 5 & $8.8 \%$ & 1 & $1.8 \%$ & 9 & $15.8 \%$ \\
\hline Total & 6 & $10.5 \%$ & 18 & $31.6 \%$ & 16 & $28.1 \%$ & 14 & $24.6 \%$ & 3 & $5.3 \%$ & 57 & $100.0 \%$ \\
\hline
\end{tabular}

Chi-square $=53.980, \mathrm{df}=20, \mathrm{p}=.000^{\mathrm{b}, \mathrm{c} *}$

*. The Chi-square statistic is significant at the .05 level.

Table 7 shows a Chi-square $(\mathrm{x})$ test result, which indicates a p value of 0.000 , which is less than 0.05 . The results reflect a significant association between the economic viability of MFM and experience. The association is significant at the 95 percent level $(\mathrm{p}<0.05)$. Therefore, the economic viability of MFM and experience are inter-related.

Table 8: Difference between performance of inventory stock management and MFM decisions

\begin{tabular}{|c|c|c|c|c|c|c|c|c|c|c|c|c|}
\hline \multirow[t]{2}{*}{ Statement } & \multicolumn{2}{|c|}{$\begin{array}{l}\text { Q7.1 } \\
\text { Strongly } \\
\text { agree } \\
\end{array}$} & \multicolumn{2}{|c|}{ Agree } & \multicolumn{2}{|c|}{ Neutral } & \multicolumn{2}{|c|}{ Disagree } & \multicolumn{2}{|c|}{$\begin{array}{l}\text { Strongly } \\
\text { Disagree }\end{array}$} & \multicolumn{2}{|c|}{ Total } \\
\hline & $\mathbf{n}$ & $\%$ & $\mathbf{n}$ & $\%$ & n & $\%$ & $\mathbf{n}$ & $\%$ & $\mathbf{n}$ & $\%$ & $\mathbf{n}$ & $\%$ \\
\hline $\begin{array}{l}\text { Q8.4 Strongly } \\
\text { agree }\end{array}$ & 4 & $7.0 \%$ & 3 & $5.3 \%$ & 1 & $1.8 \%$ & 0 & $0.0 \%$ & 3 & $5.3 \%$ & 11 & $19.3 \%$ \\
\hline Agree & 20 & $35.1 \%$ & 5 & $8.8 \%$ & 1 & $1.8 \%$ & 1 & $1.8 \%$ & 0 & $0.0 \%$ & 27 & $47.4 \%$ \\
\hline Neutral & 9 & $15.8 \%$ & 3 & $5.3 \%$ & 0 & $0.0 \%$ & 0 & $0.0 \%$ & 0 & $0.0 \%$ & 12 & $21.1 \%$ \\
\hline Disagree & 1 & $1.8 \%$ & 1 & $1.8 \%$ & 1 & $1.8 \%$ & 0 & $0.0 \%$ & 0 & $0.0 \%$ & 3 & $5.3 \%$ \\
\hline $\begin{array}{l}\text { Strongly } \\
\text { Disagree }\end{array}$ & 2 & $3.5 \%$ & 0 & $0.0 \%$ & 0 & $0.0 \%$ & 1 & $1.8 \%$ & 1 & $1.8 \%$ & 4 & $7.0 \%$ \\
\hline Total & 36 & $63.2 \%$ & 12 & $21.1 \%$ & 3 & $5.3 \%$ & 2 & $3.5 \%$ & 4 & $7.0 \%$ & $\begin{array}{l}57 \\
p\end{array}$ & $100.0 \%$ \\
\hline $\mathrm{Q} 7.1 * \mathrm{Q} 8.4$ & & Ordinal b & y Or & & Ken & 's tau-b & & & & & .504 & \\
\hline
\end{tabular}

*. The Chi-square statistic is significant at the .05 level.

Respondents from a South African local government department were asked, based on their experience, whether MFM contributes to good financial decisions for inventory stock management being made. Interestingly, Table 8 illustrates that the majority, 38(66.7 percent), of the respondents agree or strongly 
agree that MFM assists with the making of good financial decisions, regarding inventory stock management. A total of12 (21.1 percent) of the respondents indicated a neutral response to the statement, and seven (12.3 percent) of the respondents disagree that MFM helps in making good financial decisions, regarding inventory stock management. A Chi-square $(\mathrm{x})$ test was performed and the results showed a $\mathrm{p}$ value of 0.504 , which is greater than 0.05 . The results reveal that there is no statistically significant relationship between the performance of inventory stock management and use of MFM to make good decisions. These two variables are independent of each other. The association is not significant at the 95 percent level ( $p>0.05)$. Therefore, performance of inventory stock management is not related to the use of MFM for decision-making purposes.

Table 9: Difference between successful performance of inventory stock management and MFM transparency

\begin{tabular}{|c|c|c|c|c|c|c|c|c|c|c|c|c|}
\hline \multirow[t]{2}{*}{ Statement } & \multicolumn{2}{|c|}{$\begin{array}{l}\text { Q7.1 } \\
\text { Strongly } \\
\text { agree }\end{array}$} & \multicolumn{2}{|c|}{ Agree } & \multicolumn{2}{|c|}{ Neutral } & \multicolumn{2}{|c|}{ Disagree } & \multicolumn{2}{|c|}{$\begin{array}{l}\text { Strongly } \\
\text { Disagree }\end{array}$} & \multicolumn{2}{|c|}{ Total } \\
\hline & $\mathbf{n}$ & $\%$ & $\mathbf{n}$ & $\%$ & $\mathbf{n}$ & $\%$ & $\mathbf{n}$ & $\%$ & $\mathbf{n}$ & $\%$ & $\mathbf{n}$ & $\%$ \\
\hline $\begin{array}{l}\text { Q8.5 Strongly } \\
\text { agree }\end{array}$ & 10 & $17.5 \%$ & 2 & $3.5 \%$ & 0 & $0.0 \%$ & 1 & $1.8 \%$ & 0 & $0.0 \%$ & 13 & $22.8 \%$ \\
\hline Agree & 21 & $36.8 \%$ & 7 & $12.3 \%$ & 1 & $1.8 \%$ & 1 & $1.8 \%$ & 3 & $5.3 \%$ & 33 & $57.9 \%$ \\
\hline Neutral & 3 & $5.3 \%$ & 1 & $1.8 \%$ & 1 & $1.8 \%$ & 0 & $0.0 \%$ & 0 & $0.0 \%$ & 5 & $8.8 \%$ \\
\hline Disagree & 1 & $1.8 \%$ & 1 & $1.8 \%$ & 1 & $1.8 \%$ & 0 & $0.0 \%$ & 0 & $0.0 \%$ & 3 & $5.3 \%$ \\
\hline $\begin{array}{l}\text { Strongly } \\
\text { Disagree }\end{array}$ & 1 & $1.8 \%$ & 1 & $1.8 \%$ & 0 & $0.0 \%$ & 0 & $0.0 \%$ & 1 & $1.8 \%$ & 3 & $5.3 \%$ \\
\hline Total & 36 & $63.2 \%$ & 12 & $21.1 \%$ & 3 & $5.3 \%$ & 2 & $\begin{array}{r}3.5 \% \\
\mathrm{Va}\end{array}$ & 4 & $7.0 \%$ & $\begin{array}{l}57 \\
p\end{array}$ & $100.0 \%$ \\
\hline Q7.1 * Q8.5 & & Ordinal b & $\mathrm{y} \mathrm{Or}$ & & Ken & 's tau-b & & .15 & & & .083 & \\
\hline
\end{tabular}

*. The Chi-square statistic is significant at the .05 level.

Interestingly, Table 9 reveals that the majority, 46(80.7 percent) of the respondents agree or strongly agree that MFM forces employees to be transparent in inventory stock management, six (10.6 percent) of the respondents disagree or strongly disagree, and five (8.8 percent) of the respondents were neutral regarding the statement. In this regard, a Chi-square $(\mathrm{x})$ test was performed to test the relationship between performance of inventory stock management and transparency of MFM. The results showed a $p$ value of 0.083 , which is greater than 0.05 . The results reveal that there are no statistically significant relationships between the variables. Basically, these two variables are independent of each other. The association is not significant at the 95 percent level ( $p>0.05)$. Therefore, performance of inventory stock management is not related to the transparency imposed by MFM.

Table 10: Differences between the performance of inventory stock management and experience

\begin{tabular}{|c|c|c|c|c|c|c|c|c|c|c|}
\hline \multirow{3}{*}{ Statement } & \multirow{2}{*}{\multicolumn{2}{|c|}{$\begin{array}{l}7.1 \\
\text { Strongly } \\
\text { agree }\end{array}$}} & \multirow{2}{*}{\multicolumn{2}{|c|}{ Agree }} & \multirow{2}{*}{\multicolumn{2}{|c|}{ Neutral }} & \multirow[b]{2}{*}{ Disagree } & \multirow{2}{*}{\multicolumn{2}{|c|}{$\begin{array}{l}\text { Strongly } \\
\text { Disagree }\end{array}$}} & \multirow[b]{2}{*}{ Total } \\
\hline & & & & & & & & & & \\
\hline & n & $\%$ & $\mathbf{n}$ & $\%$ & $\mathbf{n}$ & $\%$ & $\%$ & $\mathbf{n}$ & $\%$ & $\%$ \\
\hline Experience0 to 3yrs & 0 & $0.0 \%$ & 1 & $1.8 \%$ & 1 & $1.8 \%$ & $0.0 \%$ & & $1.8 \% 3$ & $5.3 \%$ \\
\hline 3 to $6 y r s$ & 11 & $19.3 \%$ & & $0.0 \%$ & 0 & $0.0 \%$ & $0.0 \%$ & 60 & $0.0 \% 11$ & $19.3 \%$ \\
\hline 6 to $9 y r s$ & 11 & $19.3 \%$ & & $5.3 \%$ & 0 & $0.0 \%$ & $0.0 \%$ & 02 & $3.5 \% 16$ & $28.1 \%$ \\
\hline 9 to $12 y r s$ & 10 & $17.5 \%$ & & $8.8 \%$ & 0 & $0.0 \%$ & $1.8 \%$ & 60 & $0.0 \% 16$ & $28.1 \%$ \\
\hline 12 to $15 y r s$ & 0 & $0.0 \%$ & 1 & $1.8 \%$ & 0 & $0.0 \% 1$ & $1.8 \%$ & 00 & $0.0 \% 2$ & $3.5 \%$ \\
\hline 15yrs and above & 4 & $7.0 \%$ & 2 & $3.5 \%$ & 2 & $3.5 \% \mathrm{C}$ & $0.0 \%$ & 01 & $1.8 \% 9$ & $15.8 \%$ \\
\hline Total & 36 & $63.2 \%$ & 012 & $21.1 \%$ & & $5.3 \% 2$ & $3.5 \%$ & 04 & $7.0 \% 57$ & $100.0 \%$ \\
\hline
\end{tabular}

*. The Chi-square statistic is significant at the .05 level.

The level of agreement by respondents from a local government department of South Africa was examined, to establish whether the performance of inventory stock management is good. Table 10 shows that 48 (84.3 percent) of the respondents agree or strongly agree that performance of inventory stock management in their organization is good, and six (10.5 percent) of the respondents disagree or strongly disagree with the statement. Only three ( 5.3 percent) of the respondents were neutral about the question 
of performance of inventory stock management being good. In this respect, a Chi-square $(\mathrm{x})$ test result indicates a $\mathrm{p}$ value of 0.003 , which is less than 0.05 . The results reflect a significant association between performance of inventory stock management and experience. The association is significant at the 95 percent level $(\mathrm{p}<0.05)$. Therefore, performance of inventory stock management and experience are interrelated.

The objectives of the study were to evaluate the performance of inventory stock management and to identify factors and examine to what extent these factors influence the effectiveness of MFM on the performance of inventory stock management in South African local government. A combination of previous literature and the findings of this study formed the model presented in Table 11.The purpose of the model is to demonstrate the significant relationships of the main research variables. The analysis of the results was based on the research objectives.

Table 11: The MFM factors Model



Table 11 shows that effectiveness/efficiency of MFM has a value of $p=0.014$ direct relationships with performance of inventory stock management, while principles of MFM (sub variable) show $p=0.050$ direct relationships, with performance of inventory stock management. The economic influence of MFM has a value of $p=0.241$ direct relationships with the performance of inventory stock management, while MFM decisions (sub-variable) have a $\mathrm{p}=0.504$ direct relationship with performance of inventory stock management. Transparency of MFM has a $\mathrm{p}=0.083$ direct relationship with the performance of inventory stock management. In addition, these findings revealed no negative relationships between the variables.

Limitations: This study did not cover all local governments and was confined to only one local government of South Africa, with specific reference to KZN. Therefore, the results of the study cannot be generalized to all local governments of South Africa. Due to the complexity of local governments in South Africa, it was difficult to research every sector in every province. Further research needs to include more local governments, with a large sample because this study did not cover those areas.

\section{Conclusion and Recommendations}

The research was conducted to investigate the perceived effectiveness of MFM on the performance of inventory stock management. However, the role played by MFM in enhancing the success of local government performance, particularly in KZN, is generally well accepted today. The results of this study illustrate that inventory stock management in the public government of South Africa is performing well. The findings also provided adequate evidence, testifying that most respondents do not have sufficient understanding regarding the principles of MFM, concerning inventory stock management. However, the results of this study clearly indicate that MFM benefits the South African local government in enforcing transparency by staff. The high level of experience by staff also played a large role in providing accurate and reliable information for this study. In respect of the significances of the collective approaches, the study found that effectiveness, economic influence, and transparency of MFM have no significant relationships with the performance of inventory stock management in the local government of South Africa. Therefore, this study recommends that further research should aim to advance financial management skills in the South African local government, in order to build financial management capacity. This will allow local government to deal with inventory stock management issues and enable 
communication with other related structures, thus improving the understanding of each other's effort in the organization.

\section{References}

Abushamsieh, K., Lopez Hernandez, A. M. \& Ortiz, R. D. (2013). The transparency of government financial information systems in Arab countries: Evidence from Palestine: Journal of accounting, business \& management, 20(2), 99.

Adamauskas, S. \& Krusinskas, R. (2012). Behavioural finance efficiency under the influence of country's economic cycle. Engineering economics, 23(4), 333.

Agenor, P. R. \& Yilmaz, D. (2011). The tyranny of rules: fiscal discipline, productive spending, and growth in a perfect foresight model. Journal of economic policy reform, 14(1), 69-99.

Aikins, S. K. (2011). An examination of government internal audits' role in improving financial performance: Public finance \& management, 11(4), 333.

Alam, S. M. (2008). Economical development in the country. Economic review, 39(3), 28.

Alekneviciene, N. M. (2005). Assessing the financial health of city municipal corporations: a comparative study. Indian Streams research journal, 3(9), 2-7.

Arbe, B. (2013). Factors affecting effective management of the procurement function at Nakuru North sub-county. International journal of business \& management, 1(7), 263.

Attila, G. \& Cristina, G. A. (2010). Budgetary classifications' role in public financial management: Annals of the University of Oradea, economic science series, 19(1), 363.

Audit to build public confidence report. (2011). Available WWW:http://www.agsa.co.za/Portals/1/Audit\%20guidelines/R3\%20Reporting\%20guide\%20fi nal.pdf (Accessed 22 August 2013).

Basaran, B. (2013). Effects of operational and structural conditions on inventory management in large manufacturing enterprises. Istanbul university journal of the school of business administration, $42(1), 41$.

Bonson, E., Torres, L., Royo, S. \& Floresc, F. (2012). Local e-government 2.0: Social media and corporate transparency in municipalities. Government information quarterly, 29(2), 123.

Bovis, C. H. (2010). Efficiency and effectiveness in public sector management: The regulation of public markets and public-private partnerships and its impact on contemporary theories of public administration. European procurement \& public private partnership law review, 8(2), 187-189.

Buckuniene, R. (2002). Analyzing local government financial performance: Evidence from Brazilian municipalities. RAC - revista de administraçaocontemporanea, 17(6), 705-711.

Burja, C. \& Burja, V. (2010). Analysis model for inventory management. Annals of the University of Petrosani Economics, 10(1), 43.

Eze, N. M. \& Harrison, O. O. (2013). Financial management in local government: The Nigeria experience. International journal of financial research, 4(4), 146.

Fausto, D. (2010). Public expenditure in Italian public finance theory. European journal of the history of economic thought, 17(4), 909-923.

Graves, N. \& Dollery, B. (2009). Local government reform in South Africa: An analysis of financial management legislative compliance by municipalities. Public Administration \& Development, 29(5), 387-392.

Grimmelikhuijsen, S. G. \& Welch, E. W. (2012). Developing and testing a theoretical framework for computer-mediated transparency of local governments. Public administration review, 72(4), 564564.

Groneck, M. (2011). The golden rule of public finance and the composition of government expenditures: a growth and welfare analysis. Journal of economic policy reform, 14(4), 273-274.

Herath, S. (2012). Size of government and economic growth: a nonlinear analysis: Methodology: Ekonomskianali / economic annals, 57(194), 7.

Huefner, R. J. (2011). Internal control weaknesses in local government. CPA journal, 87(7), 26.

Jovanovic, P. \& Benkovic, S. (2012). Improvements in organizing public procurement at the local selfgovernment level in Serbia. Management, 64(5), 25-27.

Kamnikar, J. A., Kamnikar, E. G. \& Burrowes, A. (2011). Government financial management in New Zealand: A model for improving accountability to the citizenry. Journal of government financial management, 60(3), 41.

Kumar, M. \& Ganguli, S. (2009). Modelling inventory management improvement: Criticalities and recommendations. ICFAI journal of supply chain management, 6(1), 36. 
Levisauskaite, J. \& Ruskys, L. (2003). The public finance control system of the republic of Lithuania and its development. Public administration, 4(16), 7-11.

Liou, K. T. (2013). The financial crisis and the challenge of government regulation. Public performance \& management review, 37(2), 210-211.

Luby, M. J. (2013). The impact of the great recession on the financial management practices of state and local governments: part I. Journal of public budgeting, accounting \& financial management, 25(1), 160.

Mackevicius, J. \& Raulinaitiene, L. (2007). The public finance control system of the republic of Lithuania and its development. Public administration, 4(16), 6-7.

Matkin, D. S. T. (2010). Before there was Enron, there was Orange County: A study of local government financial-oversight committees. Public budgeting \& finance, 30(3), 27.

Meidunas, K. \& Puzinauskas, M. (2003). E-Governance in public financial management: An overview, IIMB management review. Indian institute of management Bangalore, 18(4), 410.

Minea, A. \&Villieu, P. (2009). Borrowing to finance public investment? The 'golden rule of public finance' reconsidered in an endogenous growth setting. Fiscal Studies, 30(1), 103-133.

Mwakibinga, F. A. \& Buvik, A. (2013). An empirical analysis of coercive means of enforcing compliance in public procurement. Journal of Public Procurement, 13(2), 245-247.

Preuss, L. (2007). Buying into our future: sustainability initiatives in local government procurement. Business strategy \& the environment (John Wiley \& Sons, Inc), 16(5), 354.

Roman, A. V. (2013). Public policy and financial management through e-procurement: a practice oriented normative model for maximizing transformative impacts. Journal of public procurement, 13(3), 338.

Seminega, W. (2012). Internal control systems for public procurement in Rwanda: Rwanda public procurement (online). Available WWW: http://rppa.gov.rw/(Accessed 24 January2014).

Siali, F., Liu, Y. \& Kie, C. J. (2013). Inventory management and logistics cost reduction: A case of a Malaysia herbal medicine company. Technology \& investment, 4(3), 211.

Smith, W. (2013). How to improve inventory-management efficiency. Controller's report, 7(6).

Tikk, J. \& Almann, A. (2011). Developments in public sector financial management in Estonia: Business \& economic horizons, $5(2), 47$.

Umakanta, M. \& Chaitanya, K. T. (2012). An EOQ model for time dependent weibull deterioration with linear demand and shortages. Scientific journal of logistics, 8(2), 124. 